"Developing the intra-firm technology transfer system at the industrial enterprise based on matrix approach"

\begin{tabular}{|c|c|}
\hline AUTHORS & $\begin{array}{l}\text { Olga Maslak } \\
\text { Natalia Grishko } \\
\text { Kateryna Vorobiova } \\
\text { Olha Hlazunova } \\
\text { Maria Maslak }\end{array}$ \\
\hline ARTICLE INFO & $\begin{array}{l}\text { Olga Maslak, Natalia Grishko, Kateryna Vorobiova, Olha Hlazunova and Maria } \\
\text { Maslak (2017). Developing the intra-firm technology transfer system at the } \\
\text { industrial enterprise based on matrix approach. Problems and Perspectives in } \\
\text { Management, 15(3), 242-252. doi:10.21511/ppm.15(3-1).2017.08 }\end{array}$ \\
\hline DOI & http://dx.doi.org/10.21511/ppm.15(3-1).2017.08 \\
\hline RELEASED ON & Wednesday, 08 November 2017 \\
\hline RECEIVED ON & Thursday, 15 June 2017 \\
\hline ACCEPTED ON & Friday, 15 September 2017 \\
\hline LICENSE & $\begin{array}{l}(\mathrm{cc}) \mathrm{EY}-\mathrm{NG} \\
\text { This work is licensed under a Creative Commons Attribution-NonCommercial } 4.0 \\
\text { International License }\end{array}$ \\
\hline JOURNAL & "Problems and Perspectives in Management" \\
\hline ISSN PRINT & $1727-7051$ \\
\hline ISSN ONLINE & $1810-5467$ \\
\hline PUBLISHER & LLC "Consulting Publishing Company "Business Perspectives" \\
\hline FOUNDER & LLC "Consulting Publishing Company "Business Perspectives" \\
\hline
\end{tabular}

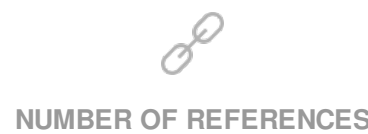

5
NUMBER OF FIGURES

7
NUMBER OF TABLES

4

(C) The author(s) 2023. This publication is an open access article. 


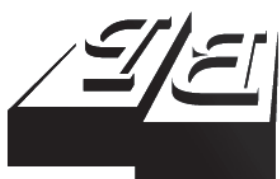

BUSINESS PERSPECTIVES

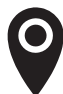

LLC "CPC "Business Perspectives" Hryhorii Skovoroda lane, 10, Sumy, 40022, Ukraine

www.businessperspectives.org

Received on: $15^{\text {th }}$ of June 2017

Accepted on: $15^{\text {th }}$ of September 2017

(C) Olga Maslak, Natalia Grishko, Kateryna Vorobiova, Olha

Hlazunova, Maria Maslak, 2017

Olga Maslak, Doctor of Economics, Professor, Head of economics department, Kremenchuk Mykhailo Ostrohradskyi National University, Ukraine.

Natalia Grishko, Ph.D. in Economics, Senior Lecturer of economics department, Kremenchuk Mykhailo Ostrohradskyi National University, Ukraine.

Kateryna Vorobiova, Ph.D. in Economics, Senior Lecturer of economics department, Kremenchuk Mykhailo Ostrohradskyi National University, Ukraine.

Olha Hlazunova, Ph.D. in Economics, Senior Instructor of economics department, Kremenchuk Mykhailo Ostrohradskyi National University, Ukraine.

Maria Maslak, Lecturer of the department of Management of organization, National Technical University "Kharkiv Polytechnic Institute", Ukraine.

\section{(ㄷ)(1) $(8$}

This is an Open Access article, distributed under the terms of the Creative Commons Attribution-NonCommercial 4.0 International license, which permits re-use, distribution, and reproduction, provided the materials aren't used for commercial purposes and the original work is properly cited.

Olga Maslak (Ukraine), Natalia Grishko (Ukraine), Kateryna Vorobiova (Ukraine), Olha Hlazunova (Ukraine), Maria Maslak (Ukraine)

\title{
DEVELOPING THE INTRA-FIRM TECHNOLOGY TRANSFER SYSTEM AT THE INDUSTRIAL ENTERPRISE BASED ON MATRIX APPROACH
}

\begin{abstract}
It is proved that the modern level of economy competitiveness has been achieved due to the scientific and technical innovations in the industrial sphere. Given the global trends, Ukraine is working out its own direction of the innovative development. To achieve the final result of innovation at the industrial enterprises, it is necessary to ensure a transfer of innovative technologies to the commercial production. Shift of the technological developments from the research units to the potential customers is usually brought about with the help of market mechanisms, i.e., launching the technologies into the market and its promotion. The article offers a matrix approach to determine the overall development of intra-firm technology transfer system considering both the internal innovation capacity and favorable external conditions. The general scheme for determining the capacity of intra-firm technology transfer system development at machine-building enterprise on the basis of correlation and regression modeling has been developed. Four main program of developing the intra-firm technology transfer system are offered. They include active development which stipulates the extensive use of endogenous factors in terms of favorable environment; moderate growth which is appropriate given certain internal and external problems of enterprises innovative development in general and technology transfer systems in particular; anti-crisis development which is appropriate either in terms of favorable environment given low internal capacity of technology development and transfer or in a difficult situation at macro-level given high transfer potential; "cryogenic" period when the entity is suffering a crisis and there are a lot of external risks, it is reasonable to resort to the "deliberate damping", being forced to suspend the innovative activity, creation and development of technology transfer system. Scientific and practical recommendations are provided to develop the intra-firm technology transfer system of the leading machinebuilding enterprises in Poltava region, such as PJSC "Kremenchug Plant of Road Machines", PJSC “Kryukov Railway Car Building Works", PJSC "Kremenchug Wheel Plant", PJSC "AutoKrAZ".
\end{abstract}

\section{Keywords}

\section{JEL Classification}

\section{INTRODUCTION}

Intra-firm technology transfer potential of the enterprise can be determined based on the level of internal and external potential transfer, the main components of which are technological, organizational, human, market, fixed and financial assets. Development of intra-firm technology transfer system is to be considered in the context of strategic management; the objective of effective implementation is to improve technical and technological state of the entity in order to achieve and enjoy technical advantages, thanks to which the company will be able to respond adequately to the requests and demands of the market, producing a competitive product manufactured with the help of one's own technology. 
Considering both the internal innovation capacity (entity's state of readiness to innovate and transfer the ideas and inventions) and favorable external conditions (level of development and stability of the legal rules and regulations in this area, demand for modernized and innovative products, great investment and innovation infrastructure, financial stability, industrial cooperation with research centers, state support of innovative enterprises, etc.) is required to determine the overall development of intra-firm technology transfer system. To evaluate the internal efficiency of technology transfer at the enterprise, it is necessary to consider a wide range of criteria with all their complexity and systemic nature. We believe that the intra-firm technology transfer system on the grounds of intrapreneurship leads to the following results: increasing innovation activity of the enterprise $\left(I_{a c}\right)$, increasing the efficiency of production and technical facilities $\left(I_{p-t}\right)$, improving financial performance $\left(I_{f p}\right)$, investment and innovation performance $\left(P_{i-\text { inov }}\right)$, innovative staff $\left(I_{s t}\right)$, marketing $\left(E_{M}\right)$, communication $\left(E_{C}\right)$ and environmental efficiency $\left(E_{\text {env }}\right)$. To determine the cumulative effect of intra-firm technology transfer, one should take into account the importance of each result determined by expertise given the specific nature of the industry:

$$
E_{K}=0.15 \cdot I_{a c}+0,16 \cdot I_{p-t}+0.14 \cdot I_{f p}+0.15 \cdot P_{i-i n n o v}+0.14 \cdot I_{s t}+0.11 \cdot E_{M}+0.08 \cdot E_{C}+0.07 \cdot E_{e n v} .
$$

Identification of the direction for entity intra-firm technology transfer system development includes the following stages (Figure 1):

- forming the performance indicator system reflecting the potential internal capabilities of developing the technology transfer system at enterprises;

- determining the most important indexes for a particular company based on the construction of nonlinear multivariate regression models;

- defining the overall development of the entity technology transfer system by comparing its internal capacity and favorable external conditions.

By analyzing and organizing the domestic and foreign sources concerning the given issues, the internal capacity performance indicator system has been identified for intra-firm technology transfer system development at machine-building enterprise:

- fixed assets renovation ratio is a partial indicator of industrial and technological capabilities of the entity that demonstrates the efficient equipment, its ability to produce modern and innovative products;

- autonomy ratio which shows the level of financial dependence of the company, the possibility of selfinnovation and technology transfer development;

- coverage ratio is an overall liquidity indicator which demonstrates the ability to cover the short-term liabilities by current assets (most easily accumulated);

- products updating ratio which reflects the share of new and modernized products;

- inventory turnover ratio which shows the stock turnover over the given period and allows detecting the increased production stock;

- number of workers, who improved their skills in the current period, reflects the level of personnel skills and capacity for creative, innovative activities;

- financial sustainability factor which reflects the correlation between the own and borrowed funds invested in the business, describes the company's ability to attract external funding for active intra-firm technology transfer innovation and development;

- capitalization rate which allows evaluating the policy of profit distribution, shows the level of net profit reinvestment and its ability to intensify production and sales activities for its own account;

- economic growth stability factor which demonstrates the importance of net profit in ensuring the equity sustainable growth, shows the stability in increasing their own funding from retained earnings and capital reserve;

- operating assets ratio which reflects the share of the equipment suitable for use in production, demonstrates the real productive capacity of the enterprise; 
1. Formation of the internal capacity performance indicator system

for inner technology transfer system development at machine-building enterprise

\begin{tabular}{|c|c|c|c|c|c|c|c|c|c|c|c|c|c|}
\hline $\begin{array}{c}\mathrm{X}_{1} \\
\text { Fixed assets } \\
\text { renovation } \\
\text { ratio }\end{array}$ & $\begin{array}{c}\mathrm{X}_{2} \\
\text { Autonomy } \\
\text { ratio }\end{array}$ & $\begin{array}{c}\mathrm{X}_{3} \\
\text { Coverage } \\
\text { ratio }\end{array}$ & $\begin{array}{c}\mathrm{X}_{4} \\
\text { Products } \\
\text { updating } \\
\text { ratio }\end{array}$ & $\begin{array}{c}\mathrm{X}_{5} \\
\text { Inventory } \\
\text { turnover } \\
\text { ratio }\end{array}$ & $\begin{array}{c}\mathrm{X}_{6} \\
\text { Number of } \\
\text { workers, who } \\
\text { improved their } \\
\text { skills in the } \\
\text { current period }\end{array}$ & $\begin{array}{c}\mathrm{X}_{7} \\
\text { Financial } \\
\text { sustainabili } \\
\text { ty factor }\end{array}$ & $\begin{array}{c}\mathrm{X}_{8} \\
\text { Capitalizatio } \\
\text { n rate }\end{array}$ & $\begin{array}{c}\mathrm{X}_{9} \\
\text { Economic } \\
\text { growth } \\
\text { stability } \\
\text { factor }\end{array}$ & $\begin{array}{c}\mathrm{X}_{10} \\
\text { Operating } \\
\text { assets ratio }\end{array}$ & $\begin{array}{c}\mathrm{X}_{11} \\
\text { Output } \\
\text { profitability }\end{array}$ & $\begin{array}{c}\mathrm{X}_{12} \\
\text { Research } \\
\text { intensity rate }\end{array}$ & $\begin{array}{c}\mathrm{X}_{13} \\
\text { Performanc } \\
\mathrm{e} \\
\text { improveme } \\
\text { nt rate }\end{array}$ & $\begin{array}{l}\mathrm{X}_{14} \\
\text { A number of } \\
\text { workers } \\
\text { involved in } \\
\text { research and } \\
\text { development }\end{array}$ \\
\hline
\end{tabular}

2. Determination of the most important indexes for a particular company

with the help of the nonlinear multivariate regression models

3. Identification of the overall development of the machine-building technology transfer system

based on the "internal capacity - favorable external conditions" matrix

\begin{tabular}{|l|l|}
\hline $\begin{array}{l}\text { Active development } \\
\text { internal capacity for active } \\
\text { innovative development and } \\
\text { sharing skills and scientific } \\
\text { innovations inside the company, } \\
\text { as well as with the customers. } \\
\text { Herewith, there are favorable } \\
\text { external conditions for the } \\
\text { technology transfer } \\
\text { development }\end{array} \quad \begin{array}{l}\text { Moderate growth } \\
\text { Development of the machine- } \\
\text { building technology transfer } \\
\text { system is complicated by the } \\
\text { intensive social, economical and } \\
\text { financial macro-level resulting in } \\
\text { the need for moderate and } \\
\text { adaptive technology transfer } \\
\text { development. Or, alternatively, } \\
\text { favorable external conditions do } \\
\text { not stimulate the company to } \\
\text { innovate }\end{array}$ \\
\hline
\end{tabular}

\begin{tabular}{|l|l|}
\hline $\begin{array}{l}\text { Anti-crisis development } \\
\text { Before developing a technology } \\
\text { transfer system, the company is } \\
\text { forced to take a number of steps } \\
\text { to overcome the destructive } \\
\text { influence of the environment, to } \\
\text { neutralize the negative impact } \\
\text { of endogenous risks. Essentially } \\
\text { the entity technology transfer } \\
\text { system is developed as part of } \\
\text { the "anti-crisis program" of the } \\
\text { enterprise }\end{array} \quad \begin{array}{l}\text { "Cryogenic" period } \\
\text { Under aggressive external } \\
\text { conditions and low internal } \\
\text { capacity of the innovative } \\
\text { enterprise, it is reasonable to } \\
\text { resort to the "deliberate } \\
\text { damping" of technology transfer } \\
\text { development, aiming at } \\
\text { mobilizing the resources for } \\
\text { smoothing the destructive } \\
\text { influence of macro economy } \\
\text { and ensuring active transfer } \\
\text { system development }\end{array}$ \\
\hline
\end{tabular}

Figure 1. Procedure for determining the capacity for intra-firm technology transfer system development at machine-building enterprise 
- output profitability;

- research intensity rate characterizes the effectiveness of innovation, namely the enterprise capacity to conduct research and development;

- performance improvement rate which demonstrates the dynamics of motivation efficiency in the company, further automated production;

- a number of workers involved into research and development.

\section{DATA ABALISIS}

To determine the most influential factors for a particular company, it is reasonable to use a correlation and regression analysis, which will define the relationship between technology transfer cumulative effect and the internal capacity of technology transfer system development at the enterprise. We used STATISTICA 10, software which simplifies the calculations.

In order to test the adequacy of correlation and regression models, $F$-test is used, which means $F$ - distribution under the null hypothesis about statistical insignificance of regression which is discarded when performing such a condition: $F_{\text {calculation }}>F_{\text {rate }}$, where $F_{\text {rate }}$ is determined by $F$ - distribution table (two degrees of freedom: $k_{1}=m, k_{2}=n-m-1$ and a given probability level $\alpha$ ).
Evaluation of equations parameters for multiple regression can be made with the help of Student's $t_{\text {-test: }} t_{\text {calculation }}>t_{\text {rate }}$ demonstrates the regressors value.

The correlation and regression results for the companies considered in the thesis (PJSC "Kremenchug Plant of Road Machines", PJSC "Kryukov Railway Car Building Works", PJSC "Kremenchug Wheel Plant", PJSC "AutoKrAZ") are given in Tables 1-4. Table 1 presents the regression values, as well as statistical significance of regression models for internal capacity of technology transfer system development at PJSC "Kremenchug Plant of Road Machines".

As you can see from the Table 1, the dynamics of the technology transfer cumulative effect at PJSC "Kremenchug Plant of Road Machines" is $98.71 \%$ predetermined by the dynamics of autonomy ratio, coverage ratio, inventory turnover ratio, financial

Table 1. Correlation and regression model of the internal capacity of technology transfer system development at PJSC "Kremenchug Plant of Road Machines"

Source: calculated by the authors.

\begin{tabular}{|c|c|c|c|c|}
\hline $\begin{array}{c}\text { PJSC "Kremenchug Plant } \\
\text { of Road Machines" }\end{array}$ & Parameters & Standard error & $\begin{array}{c}t(5) \\
t_{\text {table }}=2.57\end{array}$ & $p$ \\
\hline Absolute term $-X_{0 \ldots}$ & -0.35654 & 0.446487 & -0.79855 & 0.460781 \\
\hline$X_{2}$ (autonomy ratio) & -1.28538 & 0.259346 & -4.95624 & 0.004262 \\
\hline$X_{3}$ (coverage ratio) & 0.20270 & 0.046400 & 4.36858 & 0.007232 \\
\hline$X_{5}$ (inventory turnover ratio) & 0.04028 & 0.006419 & 6.27498 & 0.001509 \\
\hline$X_{7}$ (financial sustainability factor) & -0.11364 & 0.034004 & -3.34179 & 0.020512 \\
\hline$X_{9}$ (economic growth stability factor) & 0.97672 & 0.198987 & 4.90847 & 0.004442 \\
\hline$X_{10}$ (operating assets ratio) & 3.15350 & 1.090496 & 2.89181 & 0.034115 \\
\hline Regressive statistics & $\begin{array}{c}\text { Multiple correlation } \\
\text { coefficient } \\
R=0.9871\end{array}$ & $\begin{array}{l}\text { Coefficient of } \\
\text { determination } \\
R^{2}=0.9743\end{array}$ & $\begin{array}{c}\text { Standard } \\
R^{2}=0.9436\end{array}$ & $\begin{array}{c}\text { Approximation } \\
\text { error } \\
=0.02791\end{array}$ \\
\hline
\end{tabular}


Source: produced by the authors.

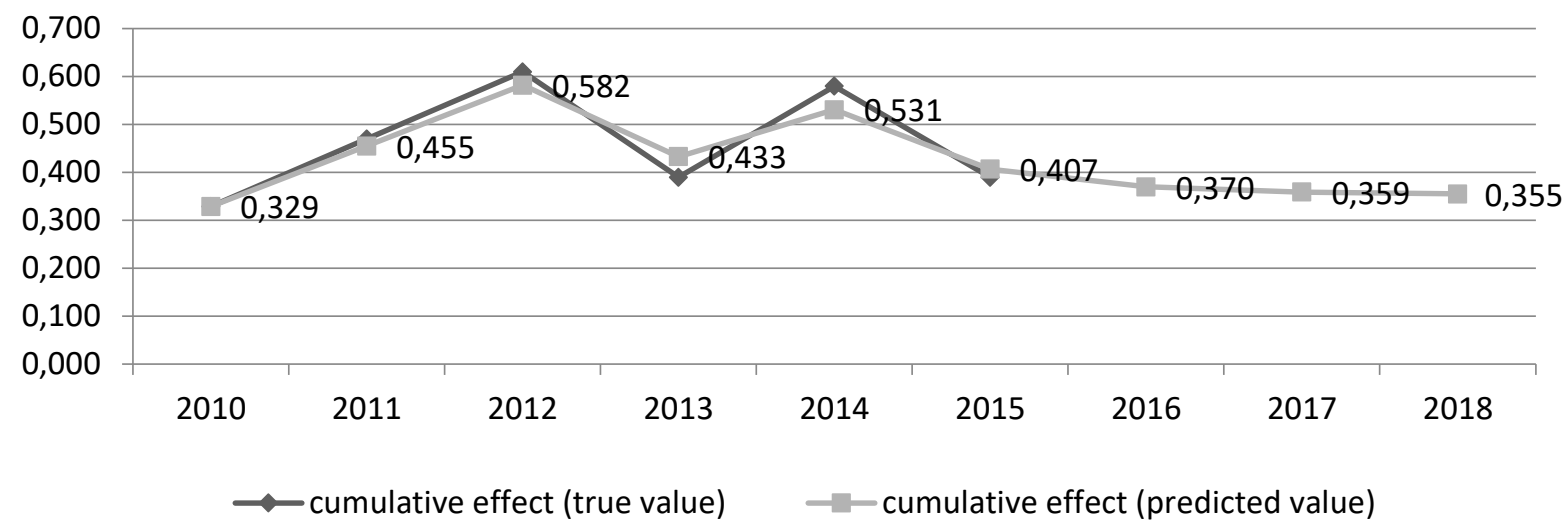

Figure 2. The dynamics of the predicted value for the cumulative effect at PJSC "Kremenchug Plant of Road Machines"

sustainability factor, economic growth stability factor and operating assets ratio.

In this case, the regression equation for the given enterprise is as follows:

$$
\begin{aligned}
& Y=-0.356-1.285 \cdot X_{2}+0.203 \cdot X_{3}+ \\
& +0.04 \cdot X_{5}-0.114 \cdot X_{7}+0.977 \cdot X_{8}+ \\
& +3.154 \cdot X_{10} .
\end{aligned}
$$

The equation results can be proved by $F$-test and Student's $t$-test, the approximation error is within the norm (up to 10\%). With the help of the equation (1), we calculated the predicted value for the cumulative effect at PJSC "Kremenchug Plant of Road Machines" (Figure 2).
As you can see from Figure 1, transfer at PJSC "Kremenchug Plant of Road Machines" cannot be regarded as a positive process, but there is no drastic deterioration in the innovative activity observed.

As to PJSC "Kryukov Railway Car Building Works", the effectiveness of its technology transfer system is mostly predetermined by the dynamics in economic growth stability factor and operating assets ratio (Table 2). In this case, only three parameters are needed to calculate the cumulative effect which is simplified significantly, compared with the results of PJSC "Kremenchug Plant of Road Machines", where 6 basic parameters have been used.

Table 2. Correlation and regression model of the internal capacity of technology transfer system

\begin{tabular}{|c|c|c|c|c|}
\hline $\begin{array}{c}\text { PJSC “Kryukov Railway Car } \\
\text { Building Works" }\end{array}$ & Parameters & Standard error & $\begin{array}{l}t(8), \\
t_{\text {table }}=2.306\end{array}$ & 6 \\
\hline Absolute term $-X_{0 \ldots}$ & 0.017452 & 0.022915 & 0.76162 & 0.468144 \\
\hline$X_{1}$ (fixed assets renovation ratio) & 0.722356 & 0.193747 & 3.72834 & 0.005802 \\
\hline$X_{8}$ (capitalization rate) & 0.095979 & 0.014335 & 6.69565 & 0.000153 \\
\hline$X_{11}$ (output profitability) & 2.364788 & 0.142126 & 16.63866 & 0.000000 \\
\hline Regressive statistics & $\begin{array}{c}\text { Multiple correlation } \\
\text { coefficient } R=0.992\end{array}$ & $\begin{array}{l}\text { Coefficient of determination } \\
\qquad R^{2}=0.984\end{array}$ & $\begin{array}{c}\text { Standard } \\
R^{2}=0.978\end{array}$ & $\begin{array}{l}\text { Approximation } \\
\text { error } \\
=0.03091\end{array}$ \\
\hline \multicolumn{5}{|c|}{$F_{\text {calculation }}(3,8)=165.24 \quad F_{\text {table }}(3,8)=4.07$} \\
\hline
\end{tabular}
development at PJSC "Kryukov Railway Car Building Works"

Source: calculated by the authors. 
Table 3. Correlation and regression model of the internal capacity of technology transfer system development at PJSC "Kremenchug Wheel Plant"

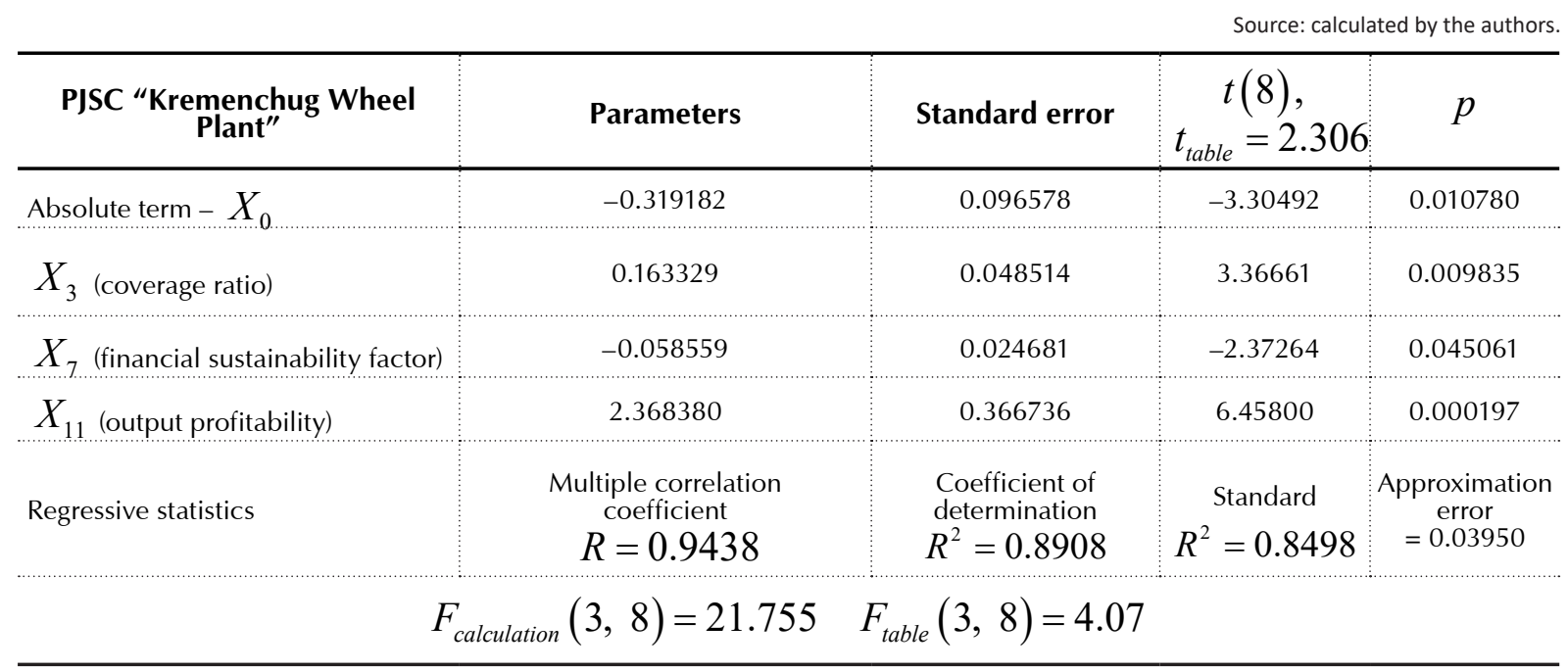

In this case, the regression equation for the given enterprise is as follows:

$$
\begin{aligned}
& Y=0.017+0.722 \cdot X_{1}+ \\
& +0.096 \cdot X_{8}+2.365 \cdot X_{11} .
\end{aligned}
$$

Interdependence of the factors is grounded by the high correlation amounting to 0.9656 , and $93.3 \%$ resulting index (technology transfer cumulative effect) can be explained by the dynamics of equation regressors.

With the help of equation (2), we calculated the predicted value for the cumulative effect at PJSC "Kryukov Railway Car Building Works" (Figure 3).
Data analysis of Figure 3 indicates the presence of negative trends in transfer at PJSC "Kryukov Railway Car Building Works" within last 3-4 years.

The dynamics of predicted values says that in the coming years the situation will not improve, although further cumulative effect value falling is not observed.

Cost-effectiveness of the intra-firm technology transfer system PJSC "Kremenchug Wheel Plant" to the great extent depends on autonomy ratio, financial sustainability factor and economic growth stability factor which determine the resultant dispersion index by $75.65 \%$.

Source: produced by the authors.

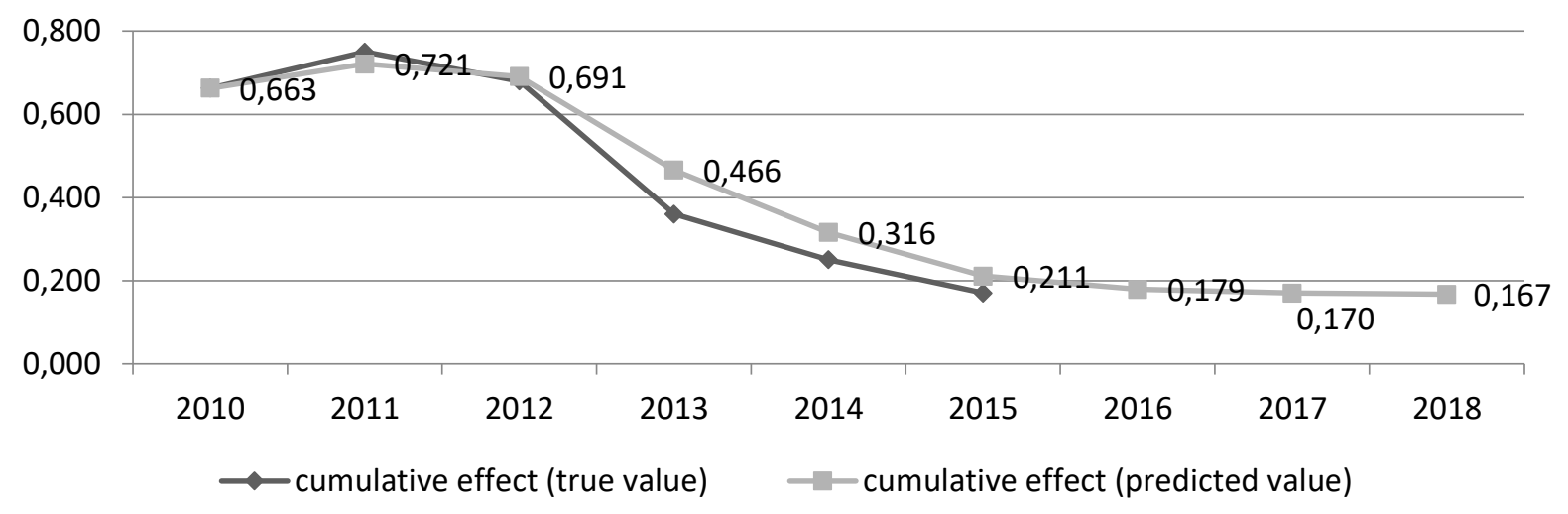

Figure 3. The dynamics of the predicted value for the cumulative effect at PJSC "Kryukov Railway Car Building Works" 


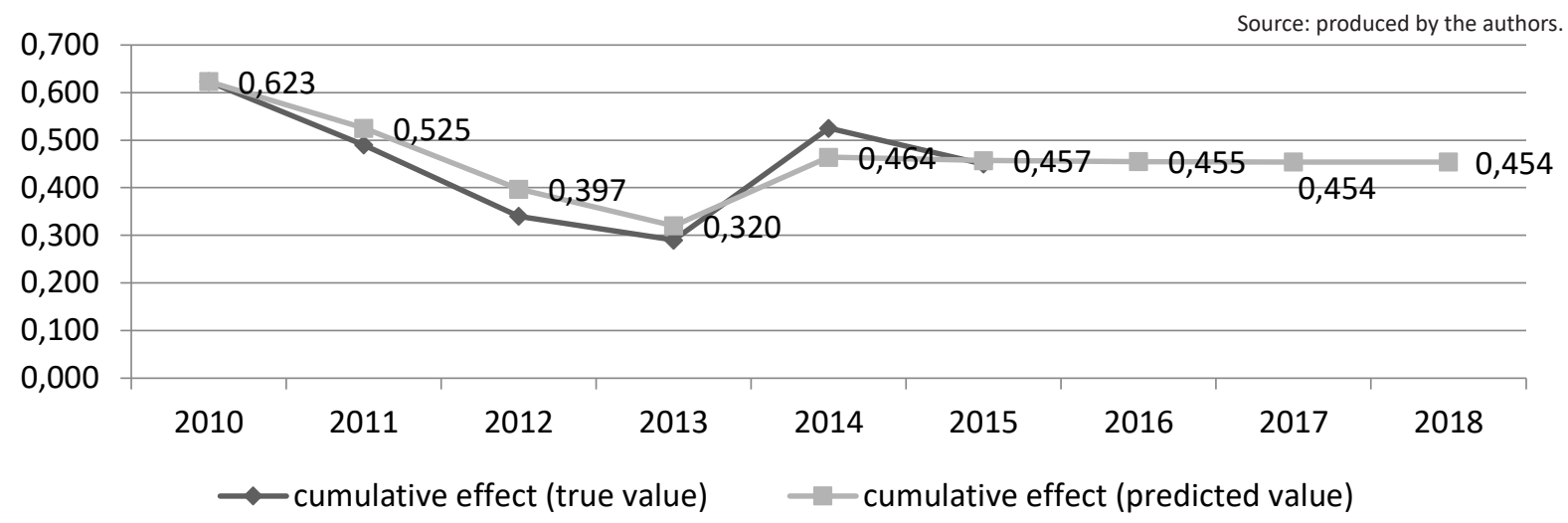

Figure 4. The dynamics of the predicted value for the cumulative effect at PJSC "Kremenchug Wheel Plant"

Other factors investigated do not have a great impact. The results of the given research are shown in Table 3. In this case, the regression equation for the internal capacity of technology transfer system is as follows:

$$
\begin{aligned}
& Y=-0.319+0.163 \cdot X_{3}- \\
& -0.058 \cdot X_{7}+2.368 \cdot X_{11} .
\end{aligned}
$$

Statistical evaluation of the resulting model shows that it is adequate and can be used to predict, as it fulfils the condition $F_{\text {calculation }}>F_{\text {rate }}$ and Student's $t$-test for all regressors (Table 3).

With the help of equation (3), we calculated the predicted value for the cumulative effect at PJSC
“Kremenchug Wheel Plant” (Figure 4).

Analysis of the predicted values for the cumulative effect at PJSC "Kremenchug Wheel Plant" shows more optimistic results in the field of inner transfer activity at the plant. There are some improvements to overcome the crisis of 2011-2013. But there is still a need to make every possible effort to ensure the innovative development for the forecast period.

As our study reveals, the intra-firm technology transfer system at PJSC "AvtoKrAZ" is essentially dependent on the autonomy ratio, a number of workers, who improved their skills in the current period, economic growth stability factor. The results and calculations are given in Table 4.

Table 4. Correlation and regression model of the internal capacity of technology transfer system development at PJSC "AutoKrAZ"

\begin{tabular}{|c|c|c|c|c|}
\hline PJSC "AutoKrAZ" & Parameters & Standard error & $\begin{array}{c}t(7) \\
t_{\text {table }}=2.365\end{array}$ & $p$ \\
\hline Absolute term $-X_{0 \ldots}$ & 0.39770 & 0.198089 & 2.00767 & 0.084656 \\
\hline$X_{2}$ (autonomy ratio) & -3.50107 & 0.569668 & -6.14580 & 0.000469 \\
\hline$X_{3}$ (coverage ratio) & 0.75366 & 0.186329 & 4.04480 & 0.004903 \\
\hline$X_{9}$ (economic growth stability factor) & 0.47340 & 0.099307 & 4.76698 & 0.002043 \\
\hline$X_{12}$ (research intensity rate) & 0.05949 & 0.018313 & 3.24836 & 0.014089 \\
\hline Regressive statistics & $\begin{array}{c}\text { Multiple correlation } \\
\text { coefficient } \\
R=0.9337\end{array}$ & $\begin{array}{l}\text { Coefficient of } \\
\text { determination } \\
R^{2}=0.8719\end{array}$ & $\begin{array}{c}\text { Standard } \\
R^{2}=0.7987\end{array}$ & $\begin{array}{c}\text { Approximation } \\
\text { error } \\
=0.06870\end{array}$ \\
\hline
\end{tabular}

Source: calculated by the authors. 


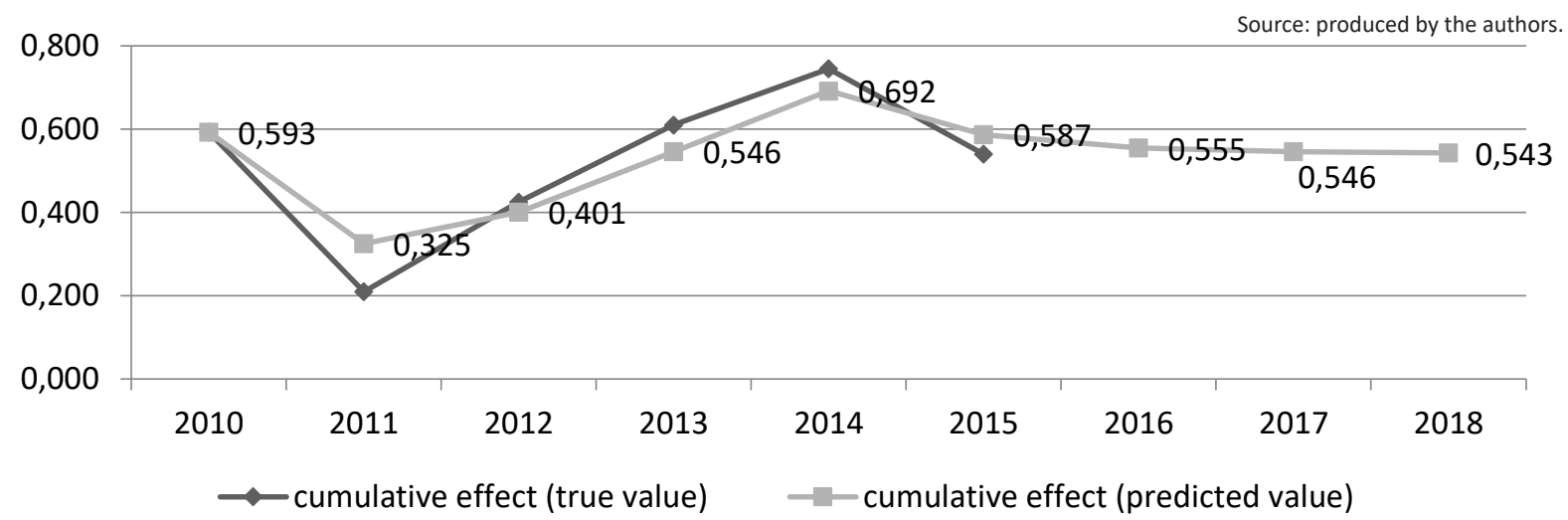

Figure 5. The dynamics of the predicted value for the cumulative effect at PJSC "AutoKrAZ"

So, the regression equation for the internal capacity of technology transfer system at the given enterprise is as following:

$$
\begin{aligned}
& Y=0.398-3.501 \cdot X_{2}+0.754 \cdot X_{3}+ \\
& +0.473 \cdot X_{9}+0.059 \cdot X_{12} .
\end{aligned}
$$

(4) On the basis of data analysis of Figure 5, we may conclude that in 2014-2015, PJSC "AvtoKrAZ" succeeded in overcoming the financial crisis of 2011. But the political crisis in Ukraine in 20142015 adversely affected the continuation of these processes. In the forecast period, we will likely see the attempts of stabilizing the economic fect) is stipulated by the equation regressors to situation.

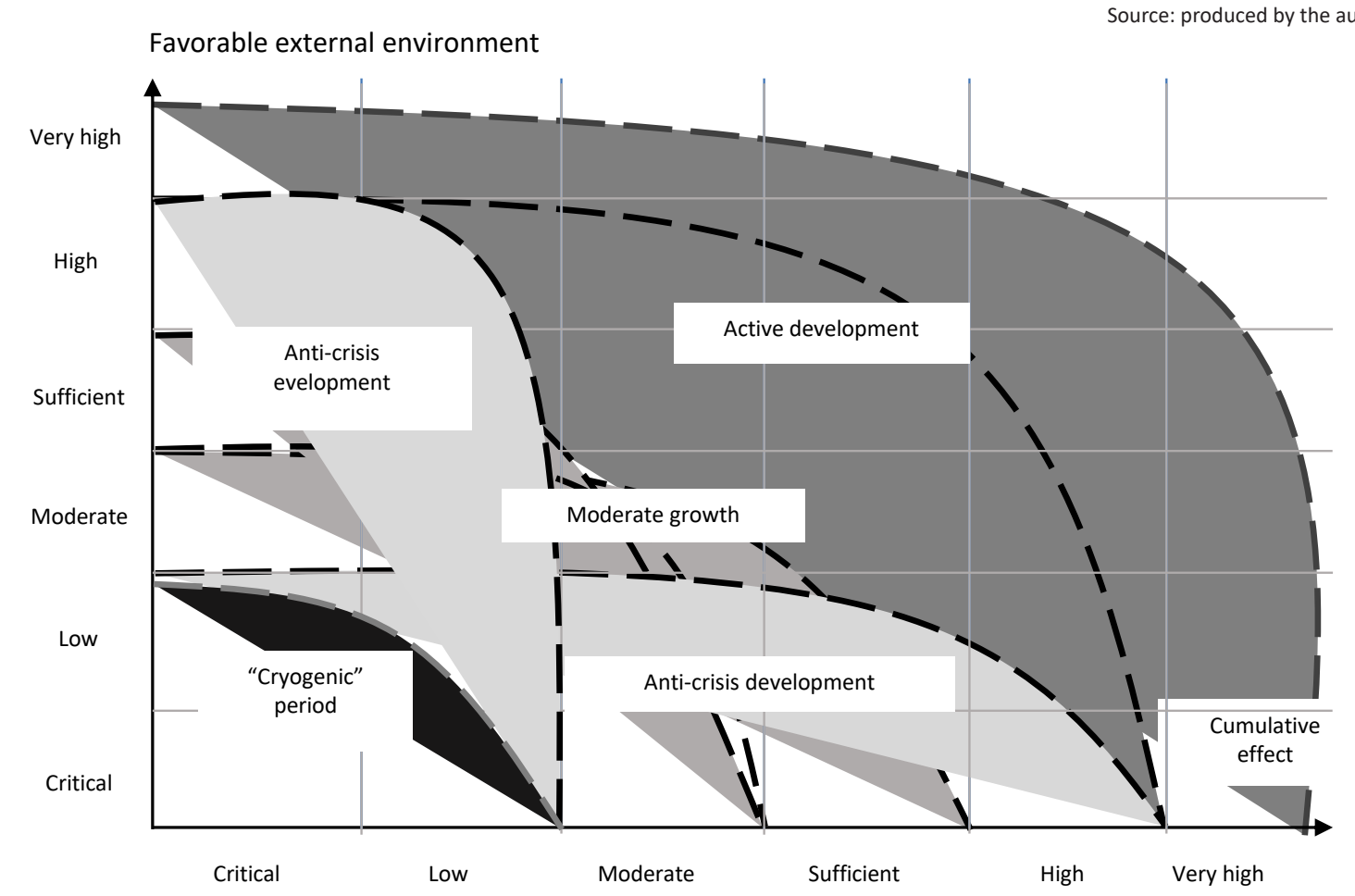

Figure 6. Matrix "internal capacity - favorable external environment" for defining the direction of technology transfer system development 
The next step in determining the direction of technology transfer development at the machine-building enterprise is to compare the internal capacity of the entity to develop and transfer the innovative technologies and the favorable external environment.

\section{RECOMMEDATIONS}

To achieve the practical purpose of the given article, the machine-building transfer activity is divided into four stages:

- active development which stipulates the intensive use of endogenous factors in terms of favorable external environment. Macroeconomics is characterized by suitable conditions for innovative activity of the economic entities as it has fixed legal rules and regulations in this area, considerable government support, favorable financial and economic factors, well-developed investment and innovation infrastructure, etc. So, having sufficient transfer capacity, stable financial position, high level of economic security, it is reasonable for the enterprise to develop the technology transfer by means of creating sustainable organizational and economic mechanism of technology development and transfer, creating and improving a technology transfer center, cooperating with external customers from research centers to innovate;

- moderate growth which is appropriate when there are some internal and external problems in the sphere of innovation in general and in technology transfer system in particular. In this case the macroeconomics poses a number of threats to the enterprise development, lack of innovative development support and, at the same time, inner transfer potential is at an acceptable level;

- anti-crisis development which is appropriate in terms of favorable environment given low internal capacity of technology development and transfer, or in a difficult situation at macro-level given high transfer potential;

- "cryogenic" period when the entity is suffering a crisis and there are a lot of external risks, it is
For this purpose, we propose to use a matrix of "internal capacity - favorable external environment" (Figure 6), which allows to identify the direction of technology transfer development under current economic conditions.

reasonable to resort to the "deliberate damping", being forced to suspend the innovative activity, creation and development of technology transfer system

Figure 7 (see Appendix) shows the directions of intra-firm technology transfer system development for machine-building companies in Poltava region. The given study indicates a rather low level of intellectual and innovation activities at the enterprises. PJSC "Kremenchug Plant of Road Machines" and PJSC "Kryukov Railway Car Building Works" have a number of internal problems in recent years, exacerbated by unfavorable external environment.

These enterprises have a "cryogenic" period in development so, first of all, they are recommended to focus on the financial policy and the readiness of production and technical facilities to innovate and conduct researches. Furthermore, companies are to ensure the implementation of preparatory actions, in particular, to renovate the technical facilities and optimize the allocation of net profit to extend internal financial resources.

PJSC "Kremenchug Wheel Plant" and PJSC "AutoKrAZ" are given some other recommendations as their direction of intra-firm technology transfer system development can be characterized as anti-crisis program. Technology transfer system development is mainly complicated by the influence of external environment requiring anti-crisis steps being taken, in particular, by optimizing the financial policy. To lessen (at least partially) the negative impact of the environment these enterprises, in our opinion, a number of steps towards a financial recovery, net income allocation optimization, increasing scientific and technical potential, as well as innovative potential of the personnel must be introduced. 
Generally, intra-firm technology transfer of the machine-building enterprises in Ukraine requires implementing the recommendations concerning the creation of appropriate financial and economic conditions and intrapreneurship as effective form of technology implementation.

\section{CONCLUSION}

Thus, improving the intra-firm technology transfer is a prerequisite for the successful implementation of innovative development in Ukraine. Development, transfer and commercialization of intellectual and innovative technologies are complicated by the influence of a number of internal and external destabilizing factors, which nature and impact are to be considered to provide a high level of adaptability and flexibility in technology transfer system at the enterprise. This article has provided the matrix approach that allows determining the overall development of intra-firm technology transfer, given the internal capacity to innovate and the favourable conditions at meso- and macro-levels.

\section{REFERENCES}

1. Diduch, D. M. (2012). The system of indexes for performance analytical support of innovation management of enterprise. Bulletin of Zhytomyr National Agroecological University, 2(2), 78-89.

2. Kostsyk, R. S. (year). Commercialization of innovative products: the nature, value and principles of. Retrieved from http://ena.lp.edu.ua:8080/ bitstream/ntb/13902/1/48_320328_Vis_727_Menegment.pdf

3. Maslak, O., Grishko, N., Hlazunova, O., Maslak, M. (2016). Intellectual capital as a factor of economic development of Ukraine. Journal of Turiba University "Acta Prosperitatis", 7, 104-118.
4. Obodets, R. V., Krasnov, O. A. (2012). Technology transfer in Ukraine: problems, present state and ways to facilitate its development. Economic Bulletin of NSU, 2, 40-45.

5. Vorobiova, K. O., Limonova, E. M. (2014). Research MNK's influence on home and destination country. European vector of economic development, 2(17), 121-130. 


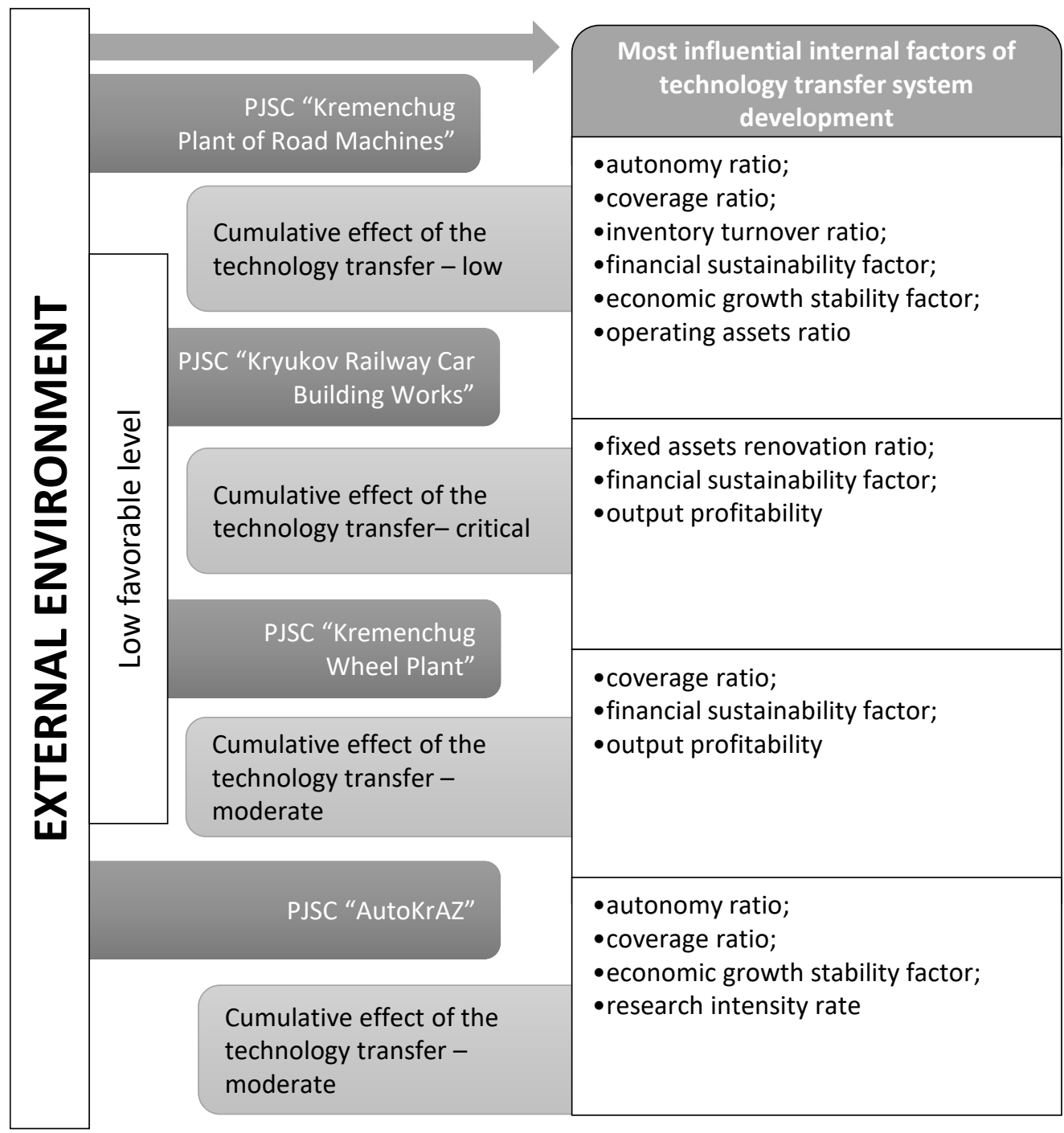

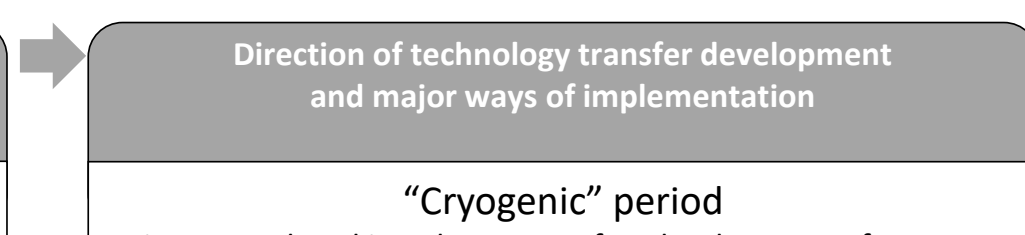

Prior to undertaking the steps of technology transfer system development, firstly, it is necessary to pay attention to the financial policy and the readiness of production and technical facilities to innovate and conduct researches

\section{"Cryogenic" period}

At the current stage the entity is to ensure the implementation of preparatory actions, in particular, to renovate technical facilities and optimize the allocation of net profit to extend internal financial resources

\section{Anti-crisis development}

Technology transfer system development is primarily complicated by the influence of external environment requiring anti-crisis steps being taken, in particular, by optimizing the financial policy

Anti-crisis development

To recover from the aggressive environmental effect it is necessary to introduce a number of steps to a financial recovery, net income allocation optimization, increasing scientific and technical potential, as well as innovative potential of the staff

Figure 7. Defining the direction of intra-firm technology transfer system development at PJSC "Kremenchug Plant of Road Machines", PJSC "Kryukov Railway Car Building Works", PJSC "Kremenchug Wheel Plant", PJSC "AutoKrAZ" 